\title{
Testosterone antagonist (flutamide) blocks ovulation and preovulatory surges of progesterone, luteinizing hormone and oestradiol in laying hens
}

\author{
P L Rangel ${ }^{1}$, P J Sharp ${ }^{2}$ and C G Gutierrez ${ }^{1}$ \\ ${ }^{1}$ Facultad de Medicina Veterinaria y Zootecnia, Universidad Nacional Autónoma de México, Cd. Universitaria, \\ 04510 Mexico and ${ }^{2}$ Roslin Institute (Edinburgh), Roslin, Midlothian EH25 9PS, UK
}

Correspondence should be addressed to C G Gutierrez; Email: ggcarlos@servidor.unam.mx

\begin{abstract}
The preovulatory release of luteinizing hormone (LH) in the domestic hen occurs after the initiation of a preovulatory surge of testosterone. The objective of this study was to determine whether this testosterone surge has functional significance in the endocrine control of ovulation. Groups of laying hens $(n=10-22)$ were treated with the androgen receptor antagonist, flutamide, at $8 \mathrm{~h}$ intervals for $24 \mathrm{~h}$ at doses of $0,31.25,62.5,125$ and $250 \mathrm{mg}$. All doses reduced egg laying $(\boldsymbol{P}<0.001)$, with the highest dose being the most effective. In a second study, laying hens $(n=9)$ were treated with $250 \mathrm{mg}$ flutamide at $8 \mathrm{~h}$ intervals for $24 \mathrm{~h}$ with a control group being given placebo $(n=10)$. Blood samples were taken for hormone measurements at $2 \mathrm{~h}$ intervals for $18 \mathrm{~h}$ starting $4 \mathrm{~h}$ before the onset of darkness. The percentage of hens laying per day did not differ between groups before treatment (control, $88 \%$ vs flutamide, $86 \%$ ). Ovulation was blocked in all hens treated with flutamide within 2 days while the control hens continued to lay at the pretreatment rate $(\mathbf{8 0} \%)$. Preovulatory surges of plasma testosterone, progesterone, oestradiol and $\mathrm{LH}$ were observed in control hens but with the exception of testosterone, flutamide treatment blocked the progesterone, oestradiol and LH surges. LH concentrations declined progressively with time in the flutamide-treated hens. It is concluded that inhibition of testosterone action blocks egg laying and the preovulatory surges of progesterone, luteinizing hormone and oestradiol demonstrating a key role for the preovulatory release of testosterone in the endocrine control of ovulation in the domestic hen.
\end{abstract}

Reproduction (2006) 131 1109-1114

\section{Introduction}

In the domestic hen, an increase in plasma progesterone, originating from the mature and maturing preovulatory ovarian follicles induces a preovulatory release of luteinizing hormone (LH) (Wilson \& Sharp 1975a, Etches \& Cunningham 1976, Wilson \& Cunningham 1984, Etches 1996), by stimulating the release of gonadotrophin-releasing hormone (Fraser \& Sharp 1978). The increase in plasma progesterone and $\mathrm{LH} \mathrm{3-6} \mathrm{h}$ before ovulation is preceded by increased plasma testosterone and plasma oestradiol (Johnson \& van Tienhoven 1980a, Etches \& Cheng 1981). Oestradiol does not participate directly in the positive feedback control of LH release (Furr \& Smith 1975, Wilson \& Sharp 1976a), but it is necessary to prime the hypothalamus to allow the positive feedback action of progesterone (Wilson \& Sharp 1976b). A role for the preovulatory release of testosterone in the ovulatory process is suggested by the finding that injection of testosterone in laying hens with mature preovulatory follicles induces ovulation (Fraps 1955,
Croze \& Etches 1980) and a preovulatory-like release of LH (Wilson \& Sharp 1976a), while blockage of testosterone action by passive immunization (Furr \& Smith 1975, Rangel et al. 2005) or active immunization against testosterone (Rangel et al. 2005) blocks ovulation. Further, active immunization against testosterone induces atresia of preovulatory yellow yolky follicles, but does not prevent their development (Rangel et al. 2005), while chronic treatment with the steroidal androgen receptor antagonist, cyproterone acetate, blocks ovulation and induces ovarian regression (Luck 1982). Fraps (1955) found that, while injection of hens with mature preovulatory follicles with progesterone induced ovulation within $8 \mathrm{~h}$, injection with testosterone induced ovulation after more than $9 \mathrm{~h}$, and suggested that testosterone must first be converted to an "active substance" before ovulation could be induced. Croze and Etches (1980) found that ovulation could only be induced using doses of testosterone which produced unphysiologically high plasma concentrations, and 
suggested that the preovulatory release of testosterone has "a preparatory or priming action on the hypothalamopituitary-ovarian system which facilitates the preovulatory release of $\mathrm{LH}^{\prime \prime}$. Our hypothesis is that blocking the action of the preovulatory surge of testosterone, with its specific antagonist flutamide (a non-steroidal androgen receptor antagonist; Mainwaring et al. 1987), will halt the predicted oviposition and the preovulatory surges of plasma testosterone, progesterone, oestradiol and $\mathrm{LH}$ in the laying hen. This study will increase our understanding of the functional significance of the preovulatory surge of testosterone. In the chicken, flutamide is known to be biologically active since administration in ovo changes sexual dimorphism in body weight and muscle characteristics of embryos (Henry \& Burke 1999) and posthatching chicks (Burke 1996).

\section{Materials and Methods}

\section{Experimental animals}

Eighteen-month-old laying hens (Gallus domesticus, $\mathrm{Hi}$ Line, supplied by Hi-Line México) beginning the second laying year were housed in individual cages with water and food ad libitum, under a $16 \mathrm{~h}$ light: $8 \mathrm{~h}$ dark schedule (light on at $0400 \mathrm{~h}$ ) and ovipositions were recorded daily.

\section{Experimental design}

\section{Experiment one}

A dose-response study was carried out to determine whether flutamide (Flubest, BEST Laboratories, México D.F.) suppresses ovulation in laying hens. Hens were assigned to five groups $(n=10-22)$ and received flutamide orally at doses of $0,31.25,62.5 .125$ or $250 \mathrm{mg}$, three times daily at 0700,1500 and $2300 \mathrm{~h}$. Pills of flutamide were administered orally. The effect of flutamide on ovulation was determined by the occurrence or absence of oviposition 2 days after the beginning of the treatment.

\section{Experiment two}

The second experiment determined the effect of the dose of flutamide found in the first experiment to inhibit oviposition on the preovulatory surges of testosterone, oestradiol, progesterone and LH. Nine laying hens (flutamide-treated group) received an oral dose of $250 \mathrm{mg}$ of flutamide every $8 \mathrm{~h}$ for $24 \mathrm{~h}$ and the control group $(n=10)$ was fed a placebo. Blood samples were taken from each hen through a teflon $20 \mathrm{G} \times 32 \mathrm{~mm}$ sterile catheter (Becton Dickinson, Izcalli, Estado de México, México) inserted into a radial vein. The catheters were kept patent by flushing with $0.5 \mathrm{ml}$ saline solution containing heparin $(50 \mathrm{UI} / \mathrm{ml}, \mathrm{PISA}$, Guadalajara, Jalisco, Mexico) following the removal of a blood sample. The hens were bled every $2 \mathrm{~h}$ for $18 \mathrm{~h}$, starting $4 \mathrm{~h}$ before the onset of darkness. In each occasion $2.5 \mathrm{ml}$ of blood was taken, using $3 \mathrm{ml}$ vacutainers containing $45 \mathrm{IU}$ of sodium heparin. After centrifugation plasma was collected and the blood cells were resuspended in $2.5 \mathrm{ml}$ of sterile physiological saline solution with $0.5 \mathrm{mg} / \mathrm{ml}$ of gentamicin (Bruluart, Tultitlan, Estado de Mexico, Mexico). The blood cells were stored at $4{ }^{\circ} \mathrm{C}$, and returned to the hens before the next blood sample was taken.

\section{Radioimmunoassays}

Testosterone, progesterone and oestradiol were measured by RIA (Coat-a-Count, Diagnostic Products Corporation, Los Angeles, CA, USA). The sensitivities of the assays were $0.04 \mathrm{ng}, 0.01 \mathrm{ng}$ and $2.5 \mathrm{pg}$ for testosterone, progesterone and oestradiol respectively. The intra-assay coefficients of variations were $2.5 \%$, $1.2 \%$ and $2.6 \%$ for the testosterone, progesterone and oestradiol assays respectively. LH was measured as described by Sharp et al. (1987) with a sensitivity of $0.036 \pm 0.09 \mathrm{ng} / \mathrm{ml}$ and an intra-assay CV of $7.6 \%$. All samples were measured in a single assay for each hormone.

\section{Statistical analyses}

The effect of different doses of flutamide on the proportion of hens laying an egg 2 days after treatment was analysed by Fisher's exact test.

A testosterone surge was defined as an increase in testosterone concentrations two standard deviations above the mean concentration of the preceding $4 \mathrm{~h}$. Hormone concentrations data were standardised to the beginning of the testosterone surge (time 0 ). The surge of progesterone, oestradiol and LH was defined as for testosterone, compared against the mean concentration of time 0 and -2 . Data were analysed by analysis of variance for repeated measurements, after logarithmic (natural log of testosterone, progesterone and LH) or square root (oestradiol) transformation of the data to correct for heterogeneity of the variance. Independent variables were the treatment, the hen nested within treatment, time and the interaction between time and treatment. Differences between treatments were analysed using the hen nested within treatment as an error term. Oviposition was evaluated by a Chi-square test, considering as the pretreatment period from 10 days before to 1 day after treatment. The post treatment period corresponds to the second day after treatment. Two out of ten control hens did not ovulate and were excluded from the hormonal analysis.

\section{Results}

\section{Experiment one}

Flutamide caused a reduction in egg laying at all doses compared with the control group $\left(\chi^{2}=21.9 ; P<0.001\right.$ 
(Table 1)). The treatment with the highest dose of flutamide $(250 \mathrm{mg})$ resulted in the greatest reduction in egg laying and was therefore used for experiment 2 .

\section{Experiment two}

The rate of egg laying in the 12 day period that preceded treatment was $88 \%$ and $86 \%$ for control and flutamide groups respectively $(P>0.05)$. Two days after treatment, all nine flutamide-treated hens failed to lay eggs while eight of the ten control hens laid (80\%).

Changes in concentration of plasma hormones were aligned in relation to the time at which plasma testosterone concentrations began to increase, designated time zero (Fig. 1). Before this time concentrations of plasma testosterone, progesterone, oestradiol and LH concentrations did not differ $(P>0.05)$ between the flutamide-treated and control groups (Fig. 1).

The eight control hens that ovulated had simultaneous surges of plasma testosterone, progesterone, oestradiol and LH (Fig. 1; B,C,D) while the two control hens that did not ovulate did not have these surges (data not shown). In the flutamide-treated hens, the testosterone surge occurred in all animals, and it did not differ $(P>0.05)$ from that observed in the eight control hens which ovulated (Fig. 1; A). In contrast, progesterone, oestradiol and $\mathrm{LH}$ preovulatory surges did not occur in the flutamide-treated hens (Fig. 1B,C,D). Furthermore, in flutamide-treated hens basal concentrations of progesterone (Fig. 1, B) and oestradiol (Fig. 1, C) did not change with time $(P>0.05)$, whilst $\mathrm{LH}$ concentrations were significantly lower after hour $0(P<0.05)$ (Fig. $1 ; D)$.

\section{Discussion}

This study demonstrates that in the domestic hen acute blockage of testosterone action during the ovulatory cycle, by the inhibition of its specific receptor with flutamide, blocks egg laying and the associated preovulatory surges of progesterone, oestradiol and LH. It therefore appears that flutamide treatment may block ovulation by preventing the preovulatory surges of progesterone and oestradiol. This conclusion is consistent with the finding that inhibition of testosterone action by passive or active immunisation against testosterone prevents oviposition in laying hens (Furr \& Smith 1975, Rangel et al. 2005).

Earlier studies suggested that testosterone must first be converted to an "active substance" before it can induce ovulation (Fraps 1955) or act to prime the hypothalamopituitary-ovarian system to facilitate the preovulatory release of LH (Croze \& Etches 1980). The possibility that testosterone must be first converted to an "active substance" to exert a direct stimulatory effect on LH release is unlikely since all evidence points to progesterone being the principal steroid directly inducing the preovulatory release of LH (Wilson \& Sharp 1975a, 1976a, Johnson \& van Tienhoven1980b) and progesterone is not a metabolite of testosterone (Norman \& Litwack 1997). The possibility that testosterone primes the hypothalamo-pituitary-ovarian system to facilitate the preovulatory release of $\mathrm{LH}$ therefore merits closer analysis. A combination of oestrogen and progesterone treatment primes the hypothalamo-pituitary system of the ovariectomised hen to make it responsive to the stimulatory action of progesterone on $\mathrm{LH}$ release (Wilson \& Sharp 1976b). It has not been established whether testosterone might mimic the priming effect of oestrogen. However, it seems unlikely that the preovulatory increase in plasma testosterone is solely responsible for priming the hypothalamo-pituitary system for the stimulatory action of progesterone on $\mathrm{LH}$ release since the base-line plasma concentrations of oestrogen in the flutamide-treated hens were not depressed and should have been adequate to exert a priming effect on the hypothalamo-pituitary system (Fig. 1C). It is therefore possible that the preovulatory peak of testosterone may act to prime the ovary to facilitate the preovulatory release of progesterone.

The principal ovarian source of progesterone for the preovulatory surge is the granulosa cell layer of the mature preovulatory follicle, with subsidiary contributions from the granulosa layer of the next most mature preovulatory follicle (Bahr et al. 1983). These granulosa cells are targets for testosterone since they contain nuclear androgen receptors (Yoshimura et al. 1993) and when granulosa cells are cultured with testosterone for $48 \mathrm{~h}$ basal progesterone production is increased (Phillips et al. 1985). Sasanami \& Mori (1999) confirmed this observation using Japanese quail granulosa cells and further demonstrated that incubation of granulosa cells

Table 1 Percentage of hens laying eggs $48 \mathrm{~h}$ of beginning treatment with a testosterone antagonist (flutamide) at different doses, three times daily for one day.

\begin{tabular}{lcc}
\hline Flutamide dose (three times per day) & Animals per group & $\begin{array}{c}\text { Percentage of animals laying an egg 2 days after } \\
\text { treatment }\end{array}$ \\
\hline $0 \mathrm{mg}$ & 10 & $90 \%$ \\
$31.25 \mathrm{mg}$ & 16 & $68.8 \%$ \\
$62.5 \mathrm{mg}$ & 16 & $31.3 \%$ \\
$125 \mathrm{mg}$ & 12 & $41.7 \%$ \\
$250 \mathrm{mg}$ & 22 & $13.6 \%$ \\
\hline
\end{tabular}



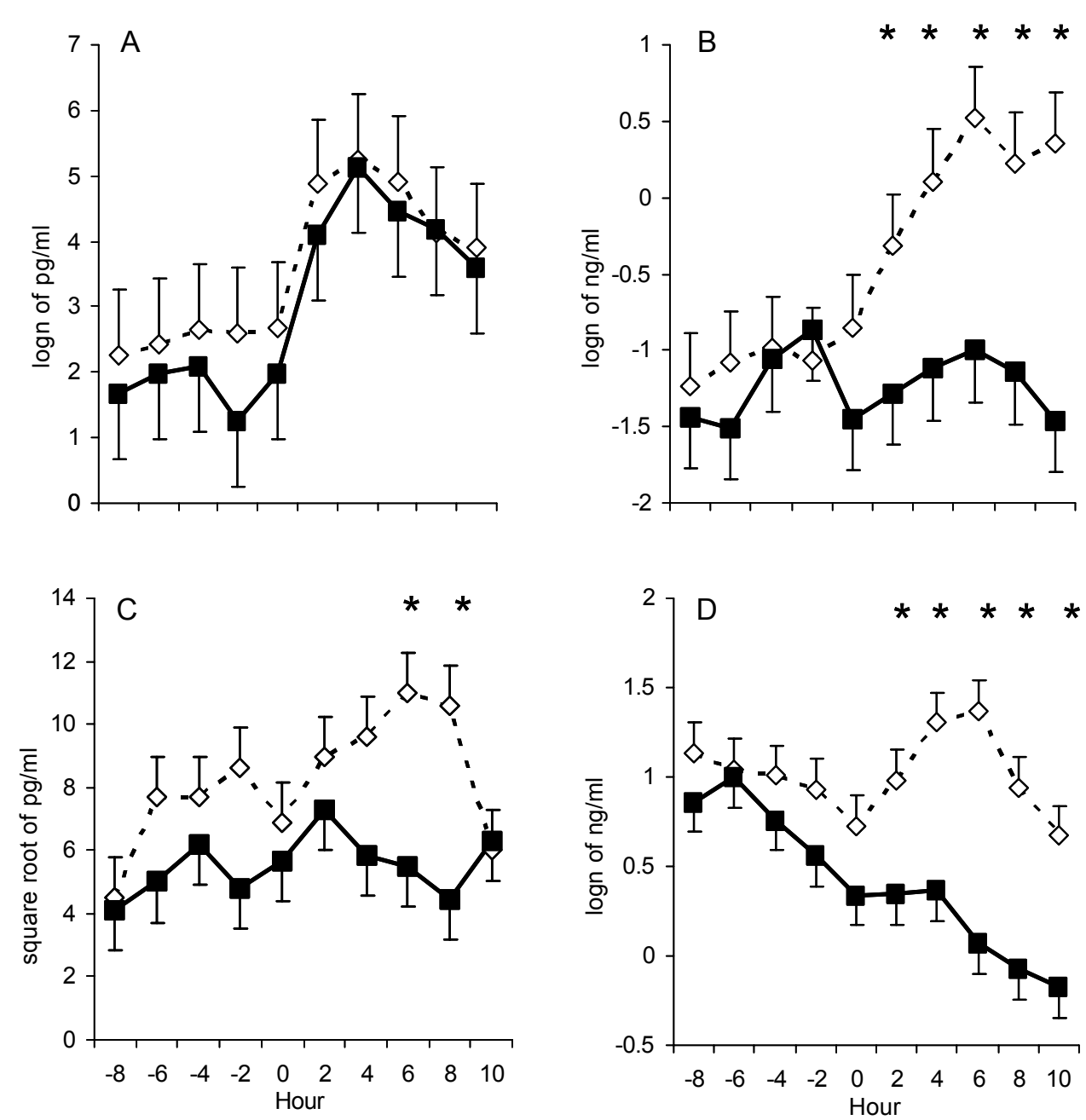

Figure 1 Testosterone (A), progesterone (B), oestradiol (C) and LH (D) concentrations in laying hens treated with 250 mg of flutamide (—- $—)$, three times daily for one day, and in control hens (- $\diamond--)$. Time 0 corresponds to the start of the testosterone peak. Values are least square means ( \pm s.E.M.). Differences between treatments are indicated by an asterisk $(P<0.05)$

for $66 \mathrm{~h}$ with testosterone enhances LH-stimulated progesterone production. This chronic stimulatory action of testosterone contrasts with studies showing that progesterone production from granulosa cells taken from F1 follicles 1.5-3.5 h after ovulation and before they are capable of ovulation is inhibited by treatment with testosterone or oestradiol (Johnson et al. 1988, Lee \& Bahr 1989, 1990). This inhibitory effect of testosterone is thought to be part of the mechanism controlling follicular maturation which is characterised by a progressive decrease in androgens and oestrogen in the thecal layer (Bahr et al. 1983). In non-mature preovulatory follicles these steroids are thought to diffuse from the theca into the granulosa layer to inhibit P450 cholesterol side chain cleavage and $3 \beta$ hydroxysteroid dehydrogenase to inhibit the synthesis of progesterone (Lee \& Bahr 1990). As a preovulatory follicle matures, concentrations of testosterone and oestrogen in the thecal layer decrease and consequently their inhibitory effects on progesterone synthesis in the granulosa cells decrease, allowing granulosa cell progesterone production to increase in preparation for ovulation. The inhibitory action of testosterone on granulosa cell progesterone production can be reconciled with its stimulatory actions if the response of granulosa cells to testosterone is related to their developmental stage. Granulosa cells from follicles which are capable of ovulation, in contrast to those from follicles which are not capable of ovulation, may respond to testosterone by increasing basal progesterone secretion and responsiveness to the stimulatory action of $\mathrm{LH}$ on progesterone production. It therefore seems plausible as suggested by Croze and Etches (1980) that the preovulatory increase in plasma testosterone facilitates the preovulatory release of $\mathrm{LH}$ by priming granulosa cells in the maturing preovulatory follicle to increase baseline progesterone secretion and responsiveness to LH. Similarly, in vitro studies with rat granulosa cells also suggest an androgen receptor-mediated stimulation of 
progesterone production (Hillier et al. 1977), while Welsh et al. (1982) showed that androgens facilitate progesterone biosynthesis induced by follicle-stimulating hormone (FSH) by enhancing the action of the $3 \beta$-HSD enzyme. Furthermore, Schomberg et al. (1978) demonstrated that implants of flutamide in pig ovarian interstitium decreases progesterone secretion by isolated granulosa cells in vitro. These observations show that in mammals testosterone plays a stimulatory role in progesterone production by granulosa cells, and the present findings in the chicken are consistent with this mechanism.

The absence of a preovulatory increase in $\mathrm{LH}$ in the flutamide-treated hens may be a consequence of the blockage of a 'priming' effect on of the preovulatory increase in testosterone on the granulosa cells of the largest preovulatory follicle, preventing an increase in responsiveness to the ability of $\mathrm{LH}$ to stimulate progesterone production. The absence of an increase in progesterone release would in turn result in the failure of the development of the positive feedback action of progesterone on $\mathrm{LH}$ release, and the generation of a preovulatory $\mathrm{LH}$ surge. The absence of a preovulatory $\mathrm{LH}$ surge may have removed a stimulus for oestrogen production (Robinson \& Etches 1986) and account for the absence of a preovulatory increase in plasma oestrogen in the flutamide-treated hens.

The increase in plasma testosterone seen in the flutamide-treated hens in the absence of a preovulatory-like release of $\mathrm{LH}$ release may be a consequence of the failure of testosterone produced by the thecal cells in the maturing follicle to inhibit progesterone synthesis in the granulosa cells, resulting in an increased substrate for further testosterone synthesis. It is suggested that the initial increase in plasma testosterone preceding a preovulatory release of LH may occur at the developmental stage of the preovulatory follicle when the decreasing testosterone produced by the theca ceases to inhibit granulosa progesterone synthesis resulting in a transitory increase in substrate for granulosa testosterone production. This increase in testosterone production may then 'prime' the granulosa cells making them more responsive to $\mathrm{LH}$ to initiate the preovulatory release of $\mathrm{LH}$. A transient increase in plasma testosterone seen before the sustained increase in preovulatory testosterone (Williams \& Sharp 1978) is consistent with this view.

The progressive decrease in plasma $\mathrm{LH}$ seen in the flutamide-treated hens may be a consequence of a stress response that is obscured in hens by the preovulatory increase in plasma LH. This conclusion is consistent with the finding that plasma LH concentrations tend to fall in chickens in which blood samples are removed frequently through indwelling brachial cannulae (Wison \& Sharp 1975b).

To our knowledge, the pharmacology of flutamide in avian species has not been determined. In humans, chronic administration of flutamide can cause liver abnormalities (Chabner et al. 2003). Nonetheless, we assume that the effects on egg laying and hormone profiles observed in these studies were due to the direct action of flutamide on androgen receptors. The former, is based on the fact that we used an acute treatment limited to the period of time where the final maturation and ovulation of the F1 will occur (Etches 1990), thus reducing the possible side effects of flutamide on other endocrine or metabolic pathways. Finally, animals resume egg laying a few days after treatment and continue to lay eggs until the end of the laying period, indicating that the liver continues to function normally.

In conclusion, testosterone antagonist (flutamide) blocks ovulation and the preovulatory surges of progesterone, LH and oestradiol in laying hens, demonstrating a key role for testosterone in the ovulatory process in hens.

\section{Acknowledgements}

This work was supported by the International Foundation for Science (grantee B-3648-1) and by Papiit, UNAM. Rangel PL was sponsored by a Conacyt student grant.

The authors wish to thank C Murcia and S Rojas for their help in hormonal assays; A Lassala, A Rodríguez, C García and E Sánchez for their help during the animal handling and sampling period; Dr G Martín for his help in the writing process.

\section{References}

Bahr JM, Wang S-C, Huang MY \& Calvo FO 1983 Steroid concentrations in isolated theca and granulosa layers of preovulatory follicles during the ovulatory cycle of the domestic hen. Biology of Reproduction 29 326-334.

Burke WH 1996 Effects of an in ovo injections of an anti-androgen on embryonic and posthatching growth of broiler chicks. Poultry Science 75 648-655.

Chabner BA, Ryan DP, Paz-Ares L, García-Carbonero R \& Calabresi P 2003 Farmacos antineoplásicos. In Goodman \& Gilman. Las bases farmacologicas de la terapeutica Vol II, pp 1405-1476. Eds Hardman and Limbird, Editor Consultor Goodman Gilman. México, McGraw Hill.

Croze F \& Etches RJ 1980 The physiological significance of androgeninduced ovulation in the hen. Journal of Endocrinology 84 163-171.

Etches RJ 1990 The ovulatory cycle of the hen. Critical Reviews in Poultry Biology 2 293-319.

Etches RJ 1996 The ovary. In Reproduction in Poultry, pp 125-166. Ed. RJ Etches. Cambridge: Cab International.

Etches RJ \& Cheng KW 1981 Changes in plasma concentrations of luteinizing hormone, progesterone, oestradiol and testosterone and in the binding of follicle stimulating hormone to the theca of follicles during the ovulation cycle of the hen (Gallus domesticus). Journal of Endocrinology 91 11-22.

Etches RJ \& Cunningham FJ 1976 The interrelationship between progesterone and luteinizing hormone during the ovulatory cycle of the hen (Gallus domesticus). Journal of Endocrinology 71 51-58.

Fraps RM 1955 Egg production and fertility in poultry. In Progress in the Physiology of Farm Animals Vol II, pp 671-740. Ed. J Hammond. London: Butterworths.

Fraser HM \& Sharp PJ 1978 Prevention of positive feedback in the hen by antibodies to luteinizing hormone releasing hormone. Journal of Endocrinology 76 181-182. 
Furr BJ \& Smith GK 1975 Effect of antisera against gonadal steroids on ovulation in the hen Gallus domesticus. Journal of Endocrinology $\mathbf{6 6}$ 303-304.

Henry MH \& Burke WH 1999 The effects of in ovo administration of testosterone or an anti-androgen on growth of chick embryos and embryonic muscles characteristics. Poultry Science 78 1006-1013.

Hillier SG, Knazek RA \& Ross GT 1977 Androgenic stimulation of progesterone production by granulosa cells from preantral ovarian follicles: Further in vitro studies using replicate cell cultures. Endocrinology 100 1539-1549.

Johnson AL \& van Tienhoven A 1980a Plasma concentrations of six steroids and LH during the ovulatory cycle of the hen, Gallus domesticus. Biology of Reproduction 23 386-393.

Johnson AL \& van Tienhoven A 1980b Hypothalamo-hypophyseal sensitivity to hormones in the hen. I. Plasma concentrations of LH, progesterone, and testosterone in response to central injections of progesterone and R5020. Biology of Reproduction 23 910-917.

Johnson PA, Green C, Lee HT \& Bahr JM 1988 Inhibition of progesterone secretion from granulosa cells by estradiol and androgens in the domestic hen. Endocrinology 123 473-477.

Lee HT \& Bahr JM 1989 Inhibitory sites of androgens and estradiol in progesterone biosynthesis in granulosa cells of the domestic hen. Endocrinology 125 760-765.

Lee HT \& Bahr JM 1990 Inhibition of the activities of P450 cholesterol side-chain cleavage and $3 \beta$-hydroxysteroid dehydrogenase and the amount of P450 cholesterol side-chain cleavage by testosterone and estradiol-17 $\beta$ in progesterone biosynthesis in hen granulosa cells. Endocrinology 126 779-786.

Luck MR 1982 Effects of an anti-androgen in the laying hen (Gallus domesticus). Journal of Reproduction \& Fertility 64 381-385.

Mainwaring WIP, Freeman SN \& Harper B 1987 Pharmacology of antiandrogens. In Pharmacology and Clinical Uses of Inhibitors of Hormone Secretion and Action, pp 106-131. Eds BJA Furr \& AE Wakeling. London: Bailliere Tindall.

Norman AW \& Litwack G 1997 Biosynthesis of Steroids. In Hormones, 2nd edn, pp 65-74. Eds AW Norman \& G Litwack. San Diego: Academic Press.

Phillips A, Scanes CG \& Hahn DW 1985 Effect of androgens and gonadotrophins on progesterone secretion of chicken granulosa cells. Comparative Biochemistry and Physiology 81A 847-852.

Rangel PL, Lassala IA \& Gutierrez CG 2005 Testosterone immunization blocks the ovulatory process in laying hens without affecting ovarian follicular development. Animal Reproduction Science 86 143-151.

Robinson FE \& Etches RJ 1986 Ovarian steroidogenesis during the follicular maturation in the domestic fowl (Gallus domesticus). Biology of Reproduction 33 1096-1105.
Sasanami T \& Mori M 1999 Effects of oestradiol-17 $\beta$ and testosterone on progesterone production in the cultured granulosa cells of Japanese quail. British Poultry Science 40 536-540.

Schomberg DW, Williams RF, Tyrey L \& Ulberg LC 1978 Reduction of granulosa cell progesterone secretion in vitro by intraovarian implants of antiandrogen. Endocrinology 102 984-987.

Sharp PJ, Dunn IC \& Talbot RT 1987 Sex differences in the LH responses to chicken LHRH-I and II in the domestic fowl. Journal of Endocrinology 115 323-331.

Welsh TH, Jones PBC, Ruiz de Galarreta CM, Fanjul LE \& Hsueh AJW 1982 Androgen regulation of progestin biosynthetic enzymes in FSH-treated rat granulosa cell in vitro. Steroids 40 691-700.

Williams JB \& Sharp PJ 1978 Control of the pre-ovulatory surge of luteinising hormone in the hen (Gallus domesticus): the role of progesterone and androgens. Journal of Endocrinology 77 57-65.

Wilson SC \& Cunningham FJ 1984 Endocrine control of the ovulation cycle. In Reproductive Biology of Poultry, pp 29-49. Eds FJ Cunningham, PE Lake \& D Hewitt. Cambridge: British Poultry Science Ltd.

Wilson SC \& Sharp PJ 1975a Changes in plasma concentrations of LH after injection of progesterone at various times during the ovulatory cycle of the domestic hen (Gallus domesticus). Journal of Endocrinology 67 59-70.

Wilson SC \& Sharp PJ $1975 b$ Episodic release of luteinizing hormone in the domestic fowl. Journal of Endocrinology 64 77-86.

Wilson SC \& Sharp PJ 1976a Effects of androgens, oestrogens and deoxycorticosterone acetate on plasma concentrations of luteinizing hormone in laying hens. Journal of Endocrinology 69 93-102.

Wilson SC \& Sharp PJ 1976b Induction of luteinizing hormone release by gonadal steroids in the ovariectomized domestic hen. Journal of Endocrinology 71 87-98.

Yoshimura Y, Chang C, Okamoto T \& Tamura T 1993 Immunolocalization of androgen receptor in the small, preovulatory, and post ovulatory follicles of laying hens. General and Comparative Endocrinology 91 81-89.

Received 12 December 2005

First decision 25 January 2006

Revised manuscript received 21 February 2006

Accepted 7 March 2006 